\title{
TECTONOSTRATIGRAPHIC CHARACTERIZATION OF THE ADJACENT PORTION TO THE SÃO VICENTE EARTHQUAKE EPICENTER IN THE SANTOS BASIN, BRAZIL
}

\author{
Camila Schweig ${ }^{1}$, João Carlos Dourado ${ }^{2}$ and lata Anderson de Souza ${ }^{3}$
}

\begin{abstract}
The São Vicente earthquake, which had occurred in the Santos Basin, approximately 200 km from São Vicente city, São Paulo state in 2008, was well detected in the global network, allowing a good determination of their focal mechanisms and associated nodal planes, sub-horizontal (strike $82^{\circ}$ ) and subvertical (strike $341^{\circ}$ ). Understanding seismic, geological and geophysical data have been necessary to determine which nodal plane is the earthquake generating fault. Gravity anomaly maps and structural contour maps allowed defining structures on regional scale. It has been observed that the epicenter is located in the high portion of the slope next to a canyon feature and the aligned graben occurrence, the Merluza Graben, coincident with Capricorn Lineament occurrence. The seismic sections have shown that in the direction of the sub-horizontal plane, less significant faults have occurred when compared to the direction of subvertical plane where there have been faults that intersect from the basement layer to the Cenozoic layers, indicating that they were activated or reactivated on neotectonic events. The mapping of a normal antithetic fault to the NS direction quite significant along the data, has suggested that a horizontal trend of this fault plane might bind to the earthquake hypocenter.
\end{abstract}

Keywords: intraplate seismicity, seismic, passive margin.

RESUMO. 0 sismo São Vicente, que ocorreu na Bacia de Santos, a aproximadamente 200 km da cidade de São Vicente (SP) em 2008, foi bem detectado na rede mundial sismográfica, o que possibilitou uma boa determinação de seus mecanismos focais e planos nodais associados, sub-horizontal (strike $82^{\circ}$ ) e subvertical (strike $\left.341^{\circ}\right)$. Para determinar qual plano nodal representa a falha geradora do sismo é necessário o entendimento de dados sismológicos, geológicos e geofísicos. Mapas de anomalia gravimétrica e mapas de contorno estrutural permitiram definir estruturas em escala regional. Observa-se que o epicentro está localizado em um alto topográfico na porção do talude próximo a uma feição de cânion e à ocorrência de grabens alinhados, o Graben Merluza, coincidente com a ocorrência do Lineamento Capricórnio. As seções sísmicas mostram que na direção do plano sub-horizontal ocorrem falhas menos expressivas se comparadas à direção do plano subvertical onde ocorrem falhas que interceptam desde o horizonte do embasamento até os horizontes cenozoicos, o que indica que as mesmas foram ativadas ou reativadas em eventos neotectônicos. 0 mapeamento de uma falha normal antitética de direção NS, bastante expressiva ao longo dos dados, permite supor que uma tendência horizontal desse plano de falha poderia se vincular ao hipocentro do sismo.

Palavras-chave: sismicidade intraplaca, sísmica, margem passiva.

\footnotetext{
1 Universidade Estadual Paulista "Júlio de Mesquita Filho" - UNESP - Rio Claro, Pós-graduação em Geologia Regional, Av. 24A, 1.515, Bela Vista, Caixa Postal 178, 13506-900 Rio Claro, SP, Brazil. Phone/Fax: +55(19) 3526-2802 - E-mail: camila.s@geoanalisys.com

2Universidade Estadual Paulista "Júlio de Mesquita Filho" - UNESP - Rio Claro, Av. 24A, 1.515, Bela Vista, Caixa Postal 178, 13506-900 Rio Claro, SP, Brazil. Phone/Fax: +55(19) 3526-9297 - E-mail jdourado@rc.unesp.br

3 Universidade Estadual Paulista "Júlio de Mesquita Filho" - UNESP - Rio Claro, UNESPetro, Av. 24A, 1.515, Bela Vista, Caixa Postal 178, 13506-900 Rio Claro, SP, Brazil. Phone/Fax: +55(19) 3526-9422 - E-mail: iataas@rc.unesp.br
} 


\section{INTRODUCTION}

The occurrence of large magnitude earthquakes in intraplate regions has been raising concerns about the geological stability of these areas and their implications for society. Besides the population question, these events can set new standards for the structural area; moreover, has been representing an increase in seismic risk associated with rich areas in oil, either exploration risks or environmental risks. The São Vicente earthquake, which had occurred in 2008, in the Santos Basin, approximately 200 km southeast of São Vicente city, São Paulo state, corresponds to this intraplate seismicity or, according to Assumpção (1998), classified as passive margin earthquake.

Due to its $5.2 \mathrm{mb}$, it was well detected on the global network, allowing its good focal mechanism determination and the associated nodal planes. To determine which plane is the earthquake generator fault, it has been necessary to know the area close to the epicenter through a series of seismic data, geological and geophysical data understanding.

The Santos Basin is the largest Cretaceous Sedimentary basin along the Brazilian coast (Corrêa et al., 2013), limited on the north by the Campos Basin by Cabo Frio High and south with the Pelotas Basin by the Platform or the Florianópolis Plataform (Mohriak, 2003). The study area covers the central portion of the basin, the region around the epicenter of São Vicente earthquake (coordinates $25^{\circ} 40^{\prime} \mathrm{S}$ and $45^{\circ} 25^{\prime} \mathrm{W}$ ) (Fig. 1).

In the epicenter region there are several geophysical seismic data collection and potential methods seeking the basin knowledge for the purpose of the hydrocarbons exploration. The scope of this work consisted in these data interpretation, characterization of operating structures in the region of São Vicente city earthquake occurrence, and thus establishing correlations between the event and its nodal planes with structures recognized in the adjacent area to the epicenter.

\section{BRAZILIAN PASSIVE MARGIN SEISMICITY AND THE SÃO VICENTE EARTHQUAKE}

Passive-margin earthquakes does not seem to be randomly distributed in space, but generally relate to areas of occurrence of great preexisting weakness zones, caused by stretch during the break and separation of lithosphere plates (Sykes, 1978; Johnston \& Kanter, 1990). According to Schulte \& Mooney (2005) these events are an important part of intraplate earthquakes.

The seismicity and the tensions recognized over the Brazilian passive margin present different aspects between the northeast and southeast region. On the northern and northeastern regions, above parallel $10^{\circ} \mathrm{S}$, the earthquakes tend to occur on onshore region over a strike-slip stress regime, resulting from the combination of EW compression forces with extensional stress perpendicular to the coast. In the Southeast region, below parallel $15^{\circ} \mathrm{S}$, the highest incidence of seismic events is on offshore region, with a predominance of a compressive regime, in areas where the continental crust was highly extended during the South Atlantic rifting in the Mesozoic (Assumpção, 1998).

The most striking examples of the continental platform seismicity and southern and southeastern slope regions are: The Tubarão earthquake in Santa Catarina state, which occurred in 1939 with 5.5 mb magnitude; Espirito Santo, along the VitóriaTrindade Chain, in 1955 with $6.1 \mathrm{mb}$ magnitude; the Campos Basin in Rio de Janeiro in 1972 with $4.8 \mathrm{mb}$ magnitude, the Rio Grande do Sul, Pelotas Basin in 1990 with 5.2 mb magnitude, São Vicente earthquake, in the Santos Basin, in 2008 with $5.2 \mathrm{mb}$ magnitude (Brazilian Seismic Bulletin - Catalog IAG-USP, 2013).

The São Vicente earthquake was recorded on 04/23/2008 at 00:00:48 pm, 04/22/2008 at 9:00:00 pm local time. Its epicenter was located on the continental platform, in the Santos Basin, approximately at coordinates: $25^{\circ} 40^{\prime} \mathrm{S}, 45^{\circ} 25^{\prime} \mathrm{W}$, with an epicenter error which can range up to $20 \mathrm{~km}$, indicating that the event occurred within the bathymetry range of 200-600 m. The hypocenter was calculated by the pP phase, using the velocity model for the sedimentary units of the Santos Basin and set the depth of $17.4 \mathrm{~km}$ in the lower crust (Assumpção et al., 2011).

Both polarity records of the $\mathrm{P}$ wave either of the regional stations or teleseismic located in different quadrants, have shown a roughly NS nodal plane, allowing to define the orientation of the fault of $341^{\circ}$ and dip of $89^{\circ}$. The displacement vector angle (slip) was set to $93^{\circ}$. With the ratio amplitude analysis of the pP/P phases another nodal plan had been established, having approximate direction EW, dipping to the south, with the oriented fault of $82^{\circ}$ and dip $3^{\circ}$. The displacement vector angle (slip) had been set to $11^{\circ}$ (Assumpção et al., 2011) (Fig. 2).

The data analysis obtained, allows two possibilities for the fault, one subvertical fault plane oriented NNW-SSE, and another sub-horizontally fault plane oriented approximately EW (Fig. 3).

\section{MATERIALS AND METHODS}

The methodology applied in the characterization of active structures in the epicenter of the São Vicente earthquake region consisted in interpretation of the 2D seismic reflection and gravimetric data. Later, the result correlation of the geophysical data interpretation with the parameters obtained for the São Vicente earthquake had been done. 


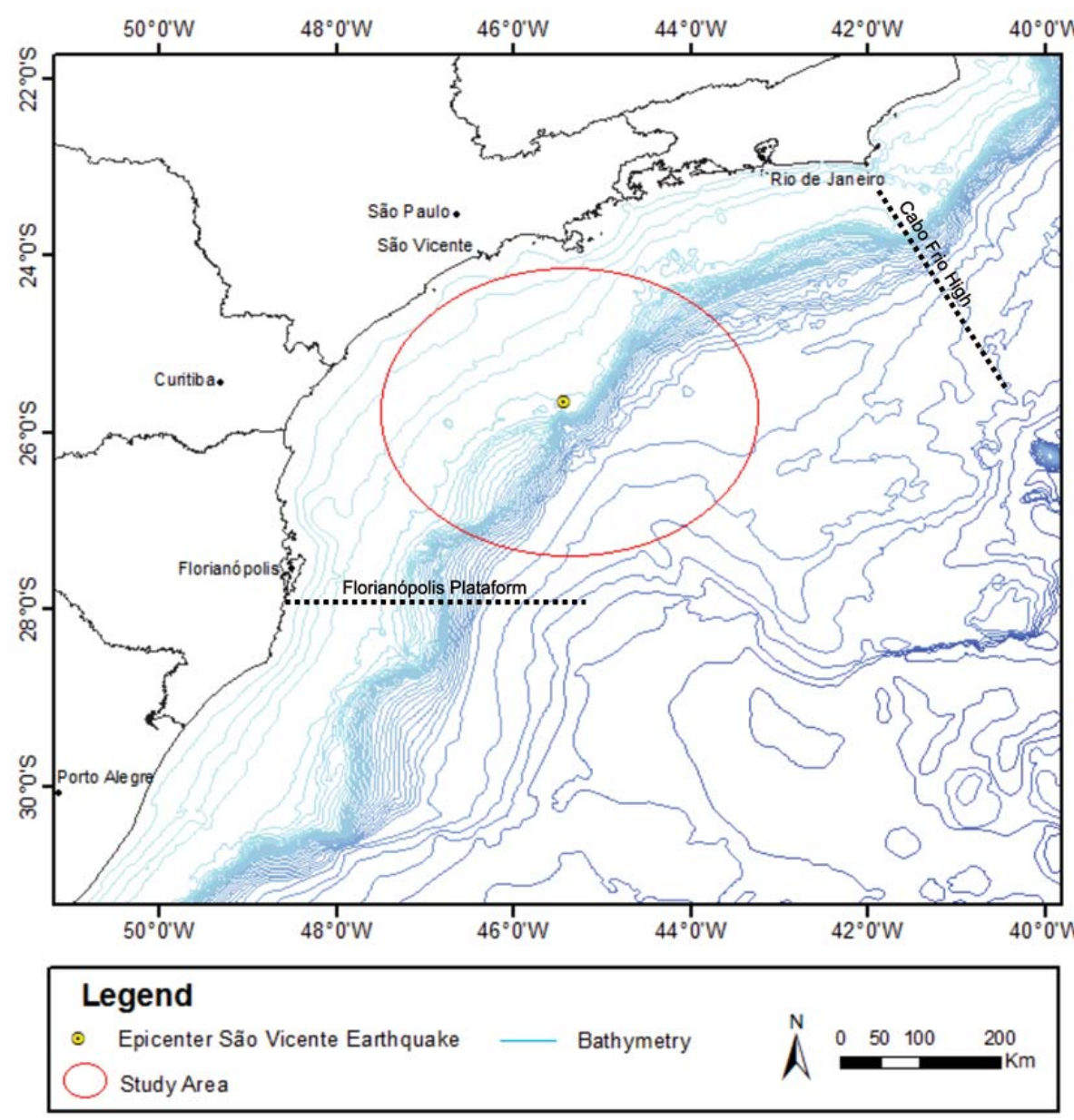

Figure 1 - Location map of the study area.

The dataset used in this work had been provided by "Banco de Dados de Exploração e Produção" (BDEP) administered by the "Agência Nacional do Petróleo, Gás Natural e Biocombustíveis" (ANP) within the gratuity policy for universities. Seismic reflection data corresponding to part of the survey called "0228_Santos_3C", "0134_Santos_1A", "0140_Santos_1A", "0231_Santos_18A", "0248_Santos_1A" and "0247_Merluza_13A"; well data of surveys called "1BSS_BS", "1SCS_SC" and "1SPS_SP" and gravimetric data from the marine survey called "Santos recognition p0141" (Fig. 4).

The seismic interpretation had been based in Vail (1987) suitable for stratigraphic analysis and Brown (2004) suitable for structural analysis. The layers considered important in the evolution of the basin, which present themselves as good seismic markers along the data had been mapped and calibrated from the checkshot data (well points with time and depth know) and geophysical well logs. The following steps consisted in carrying out the identification of geological structures.
To better understand the structural framework of the area, were built structural contour maps for each of the time layers interpreted on seismic sections. They were generated by interpolation of the data UTM $(X, Y)$ and time $(Z)$ for each layer in a regular grid of $0.1 \mathrm{~km}$, using the minimum curvature method, and then their interpretation had been made.

The Free-air and Bouguer anomaly maps had been made by interpolation of gravimetric data on a regular grid of $5.0 \mathrm{~km}$ using the minimum curvature method. In order to eliminate the noises and to improve the visualization of the gravimetric gradients had been applied filtering techniques to the data: a low pass filter, which consists to reject only one high frequency band unwanted by analysis of the radial power spectra obtained with the application of Fourier fast transformed (Geosoft, 2010), and the directional cosine filter, which aims removing directional features from the grid (Geosoft, 2010). After filtering, the final maps had been generated and their interpretation had been made. 


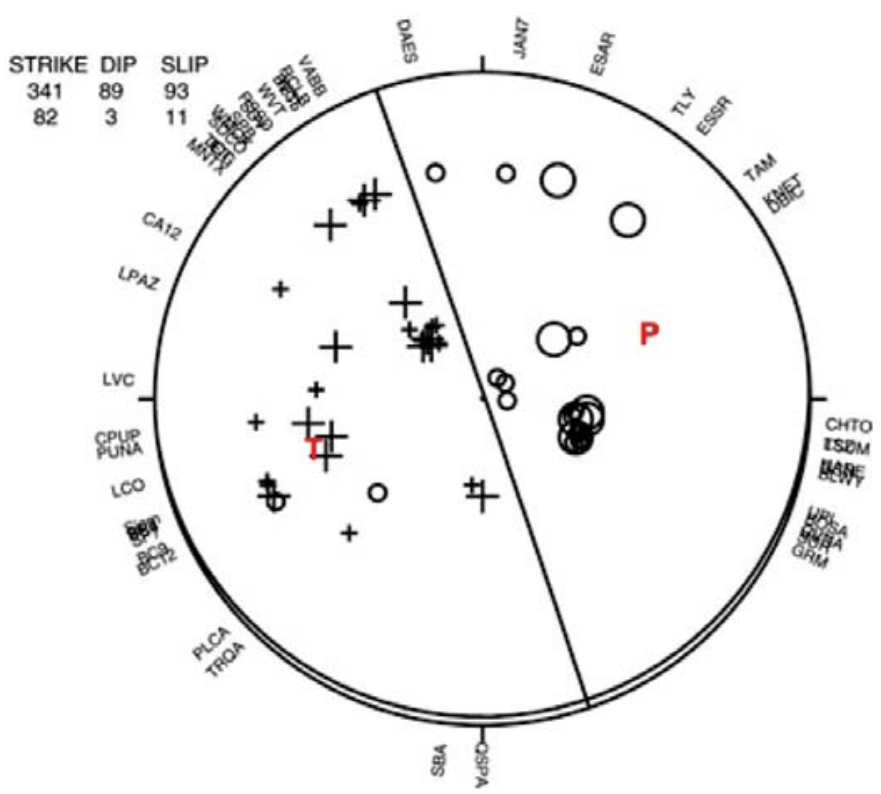

Figure 2 - The focal mechanism solution obtained for the São Vicente earthquake. The first motion of the $\mathrm{P}$ wave is represented by crosses (push) and circles (pull). P and T indicate the tension direction. Modified from Assumpção et al. (2011).

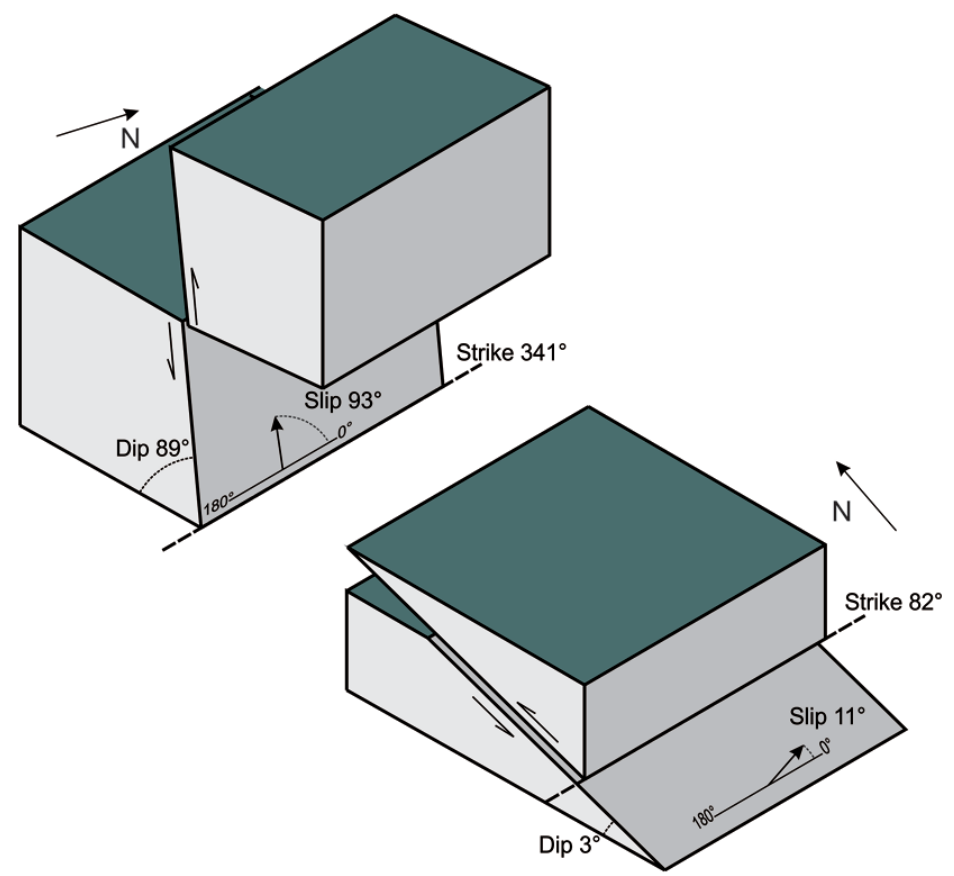

Figure 3 - Schematic block representation for two possible interpretations of the nodal planes.

\section{RESULTS}

The seismic data stratigraphic interpretation allowed to identify and map ten layers: Basement; Pre-Salt Top, Salt Top; Albian; Late Santonian; Campanian; Cretaceous Top; Late Eocene; Middle Miocene; and Seabed. Beyond representing stratigraphic landmarks important in the Santos Basin evolution, the mapped layers have been good seismic reflectors, in order to date the period and understand the evolution of the faults identified in the structural interpretation step (Fig. 5).

In the seismic data structural interpretation had been possible to visualize and map features that reflect the structural style and tectonic typical of the marginal basins: synthetic and 


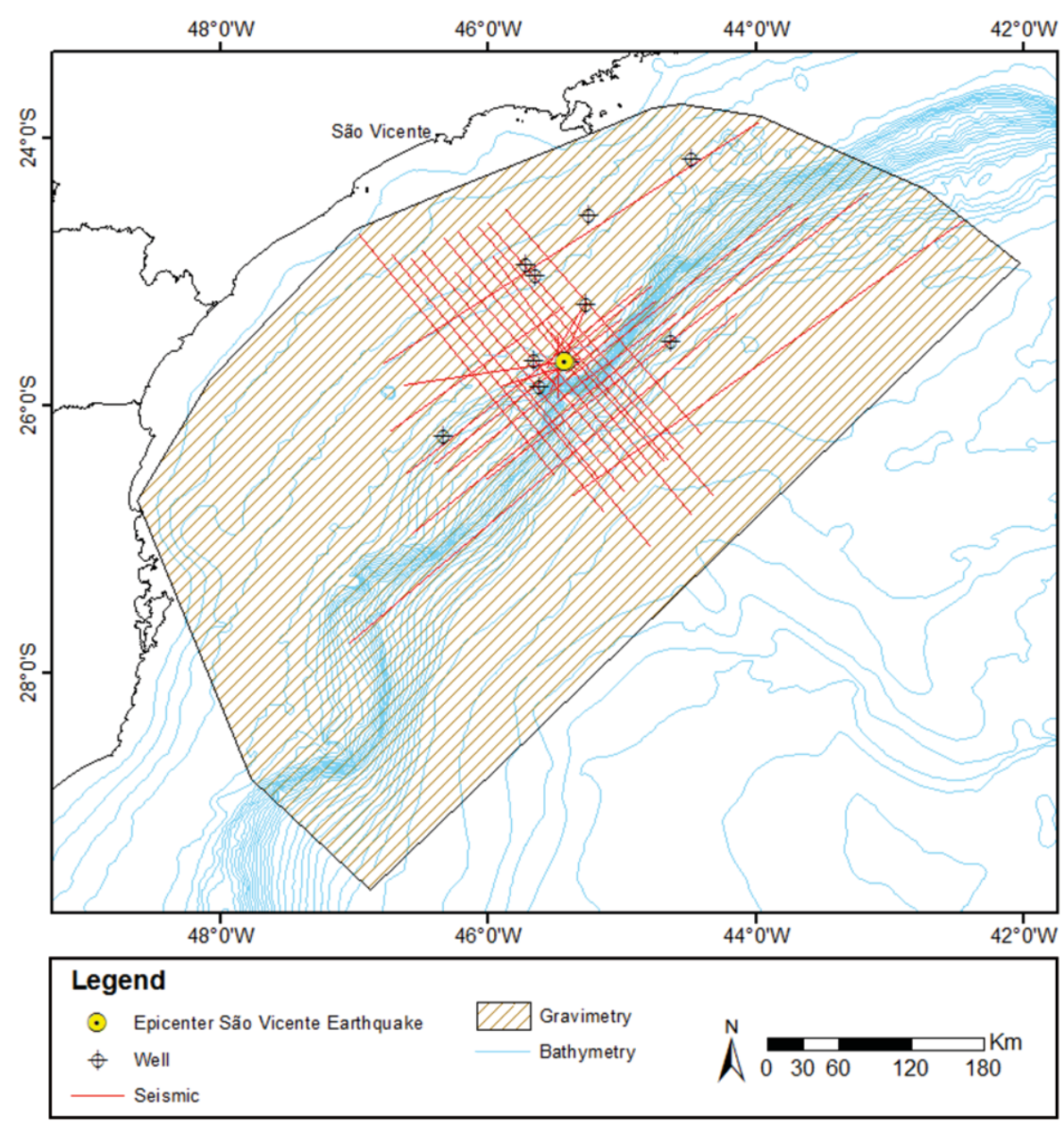

Figure 4 - Database location map used.

antithetic faults with high block alternating (horsts) and lows ones (graben); listric faults, domino faults, which predominate in the shallower layers in the basin, normal faults accommodation Post-Salt, negative flower structures in some sections of strike direction; basin hinge line or "Charneira de Santos" structure clearly visible along all the basin western edge and in the dip direction sections; and halokinetic structures associated with the Salt Top layer, such as diapirs, walls, salt pads and mini basin formation (Fig. 6).

The structural contour maps in time for each interpreted layers as the gravimetric maps have shown that they are structured and elongated in the NE-SW direction and generally dipping to the southeast, coincident with the Precambrian structure direction of the grounding in the continent. In addition to evidence a trend in NW-SE direction that intersects these elongated features, which has been probably related to the basin transfer zones.

\section{DATA INTEGRATION AND DISCUSSIONS}

In order to conduct an analysis that allows characterizing the region around the epicenter, it is essential to integrate the information from the geophysical data interpretation with the parameters obtained for the São Vicente earthquake, starting from a regional scale approach to visualize in detail the structures. Therefore, data from free-air gravimetric anomaly had been integrated with the epicenter location and the earthquake nodal planes, in addition to the main geological features on a regional scale recognized in the study area (Fig. 7).

The correlation allows us to observe that the epicenter of the earthquake is located on a high gravimetric. The regional geologic features recognized in the area present NW-SE trending faults represented by the transfer zones, and a NE-SW trending faults marked by the occurrence of elongated structures, represented here by the Cabo Frio fault zone and the basin hinge line. It can also be observed that the Lineament Capricorn 


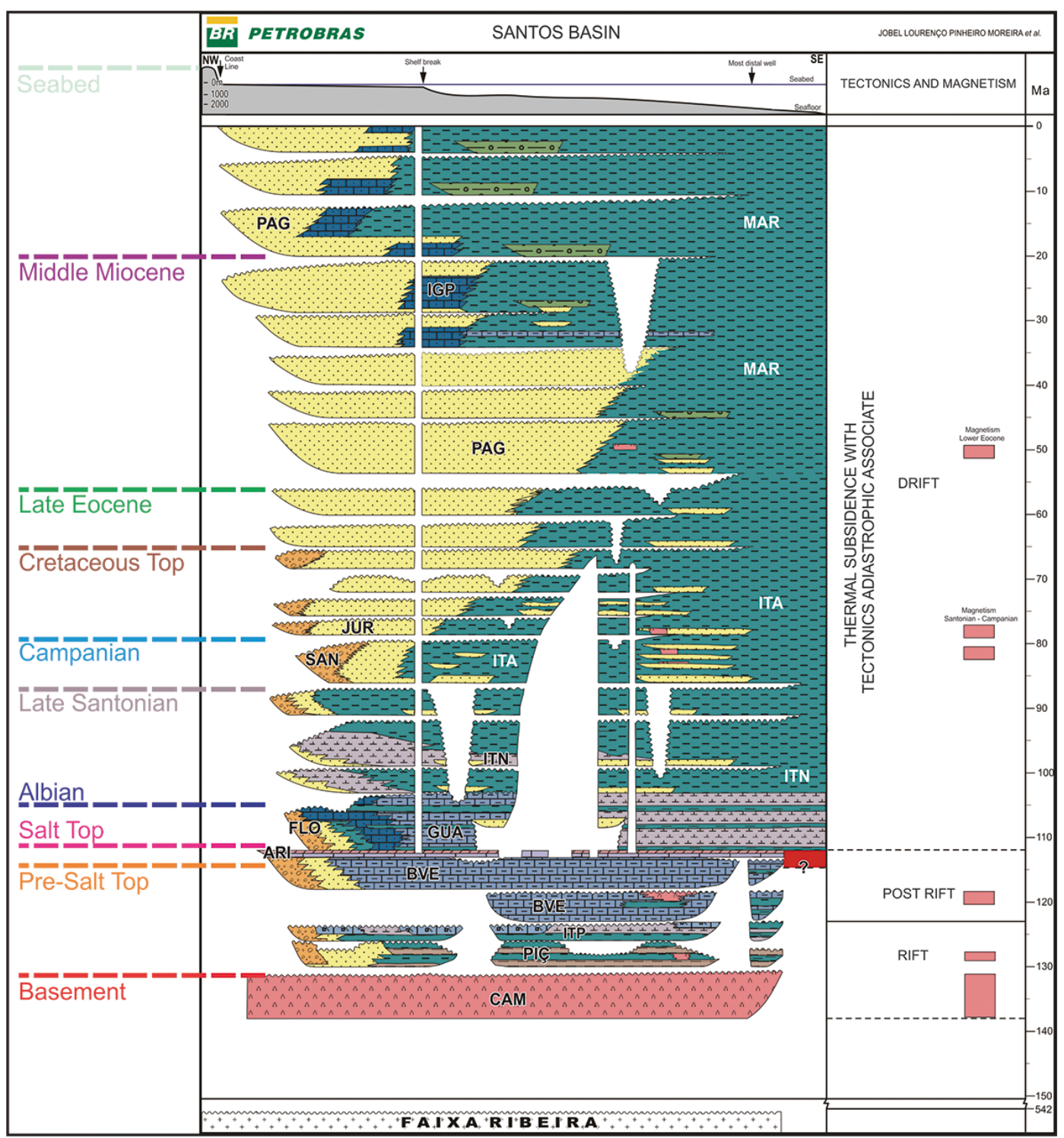

Figure $\mathbf{5}$ - Chronostratigraphic interpreted layers and incorporated into the stratigraphic chart of the Santos Basin. Modified from Moreira et al. (2007).

recognized by Bueno (2004) has its occurrence zone coinciding with the earthquake's epicenter location. In the nodal plane integration analysis with the gravimetric data, both directions do not show a clear correlation with regional features displayed on the free-air gravimetric anomaly map.

Seeking for a better understanding of the structural framework of the area, faults had been traced on the structural contour maps; the structures identified on seismic sections, the criteria used had been the density of contour lines, sudden changes in gradient and alignment structures. The result shows the dominance of two main directions over the maps, NW-SE and NE-SW, again coincident with the basin structure main directions.
The contour map structural integration with nodal planes obtained for the earthquake shows that the sub-horizontal plane intersects the identified structures on the map and a structure aligned in that direction can not be visualized, as well as the subvertical nodal plane that shows equally a difficult structural correlation. On the map of the Pre-Salt Top layer and Salt Top layer have been observed a NS structure marked by a sequence of aligned grabens, reflecting on the overlapping layers. This feature is most probably associated with the Graben Merluza occurrence zone. On the seabed layer map a gap occurrence in NW-SE direction can be observed, which corresponds to a canyon observed in the slope basin. In general, it has been observed that the epicenter is 


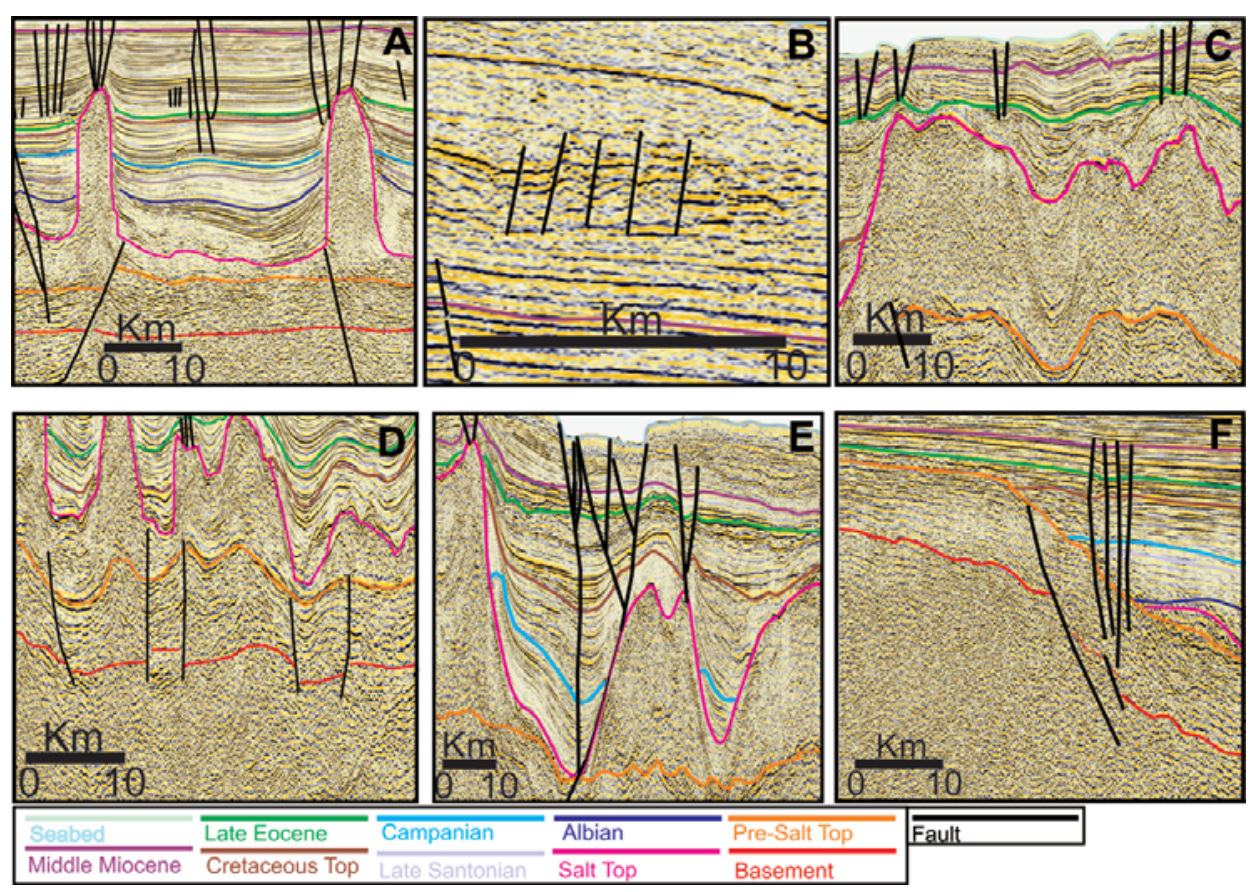

Figure 6 - Stratigraphic layers interpreted and major structural features mapped. A) synthetic and antithetic faults, salt diapirs and normal faults accommodation Post-Salt; B) domino faults; C) salt walls and mini basin formation; D) faults with high block alternating (horstes) and lows ones (graben); E) negative flower structures; and F) basin hinge line or "Charneira de Santos".

located on a topographic high in the slope portion of the basin very close to the feature that represents the Graben Merluza (Fig. 8).

Starting up for a greater detail range, seismic section interpretations had been jointly analyzed, restricted the nodal planes directions, in order to quantify and qualify the structures present in these directions and define the their continuity along the data. The dataset analyzed restricted to the influence zone of the sub-horizontal nodal plane shows the occurrence less significant faults when compared to the subvertical nodal plane influence zone analysis, which shows the occurrence of faults very expressive, most of them intercepting Cenozoic layers, many of them associated with the steep steps found in the Seabed layer. A present feature in sections 0231-1328 and 0231-1331 has been quite evident, it is a normal antithetic fault with large tailings, associated with a negative flower structure, which intercepts the entire sedimentary and extending to the Basement layer (Fig. 9).

As the result of the correlation of both nodal planes assumes a rectilinear view along the seismic sections, restricted directions plans. From the visualization of normal fault antithetic NS in sections 0231-1328 and 0231-1331, it was mapped in order to establish its trajectory over the seismic data. Knowing two points of the fault plane (one on the Basement layer and another on the
Seabed layer), and the basement depth at the epicenter location, which according to Constantino (2012) is $8.5 \mathrm{~km}$, the average dive plan mapped fault had been able to be projected, which dips on an average of $40^{\circ}$ to the west (Fig. 10).

Figure 11 shows the 0248-0047 section which is about 900 meters from the epicenter, with the feature corresponding to Merluza Graben and associated to the antithetic fault, located near the hypocenter.

In relation to the stress analysis, when assuming the fault plane with direction $82^{\circ}$, the most favorable orientation for maximum compression (S1) would be $52^{\circ}$. In case of failure subvertical NE, the most favorable orientation for maximum compression (S1) would be $11^{\circ}$. This result is consistent with the proposal presented by Assumpção et al. (2011), that suggests the São Vicente earthquake had occurred in the transition zone between horizontal compression and horizontal extension, with approximately S1 dipping to NE, out of the maximum load, which is concentrated at SW of the epicenter on the basin slope.

\section{CONCLUSIONS}

The integration of seismic, geological and geophysical data had allowed satisfactorily the area characterization around the epicenter of the São Vicente earthquake. 


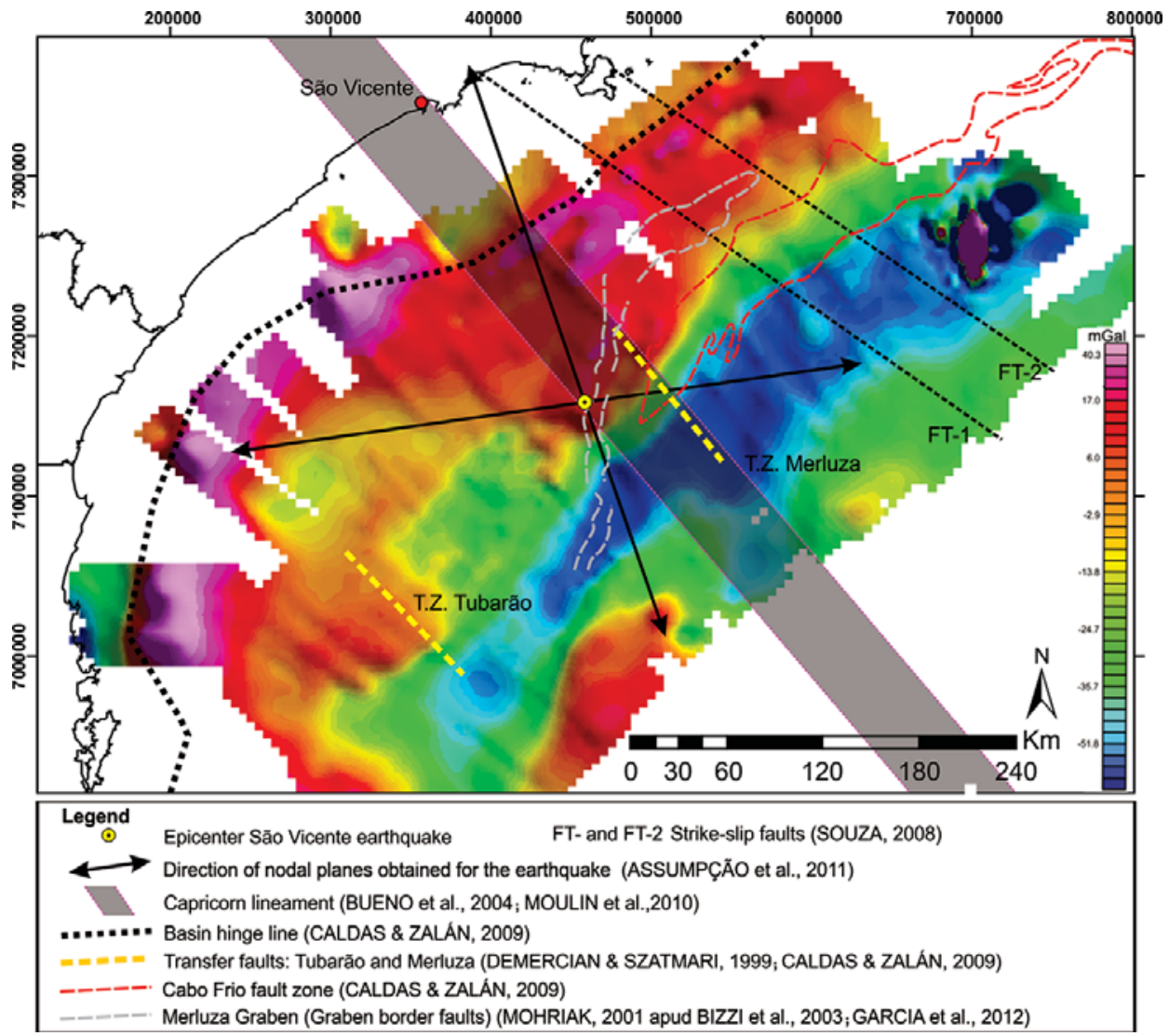

Figure 7 - Correlation of the free-air gravimetric anomaly data with the epicenter data, and geological features nodal plans recognized in the study area.

The gravity anomaly maps and contour structural maps allowed defining structures on a regional scale. Major structural directions area had been recognized: NE-SW characterized by anomalies defined by elongated crescent isogonics contour, and NW-SE that intersects these anomalous elongated features. It is possible to conclude that the earthquake epicenter is located in a high gravimetric and topographic slope in the basin portion, very close to a canyon feature and near the Graben Merluza occurrence, besides its location has been coincident with the Capricorn Lineament occurrence.

The seismic data interpretation had allowed mapping the features in greater detail, reflecting the structural and tectonic style typical of marginal basins. The interpretation analysis of seismic sections, restricted to the directions of the nodal planes, shows that the sub-horizontal direction has evidenced the occurrence of some little significant faults, which are primarily associated with the rifting and halokinesis processes. In relation to the subvertical nodal plane, quite significant faults occur, most of them intercepting Cenozoic layers, indicating that they had been activated or reactivated on neotectonic events.
The normal antithetic fault mapping approximately NS had displayed expressively over the seismic data allowing to correlate this grabens aligned, representing the Graben Merluza with diapirs bordering the fault to the east. The data difficult visualization in the portion below the Basement layer along the seismic sections only allows inferring hypotheses on the behavior of the mapped fault. A purely geometric analysis, assuming that faults tend to flatten as the depth increases until a detachment zone characterized by brittle-ductile transition (Gibbs, 1984; Moores \& Twiss, 1992), has revealed that the antithetic normal fault projection mapped would reach the hypocenter with an approximately horizontal angle. In the subvertical plan analysis, this particular fault would reach the hypocenter at an angle an approximated diving angle of $89^{\circ}$, which does not exclude the possibility that another fault unmapped favors this condition (Fig. 12).

\section{ACKNOWLEDGEMENTS}

The authors would like to thank to the "Banco de Dados de Exploração e Produção" (BDEP) for providing geophysical data necessary for the execution of this work. The authors would also 


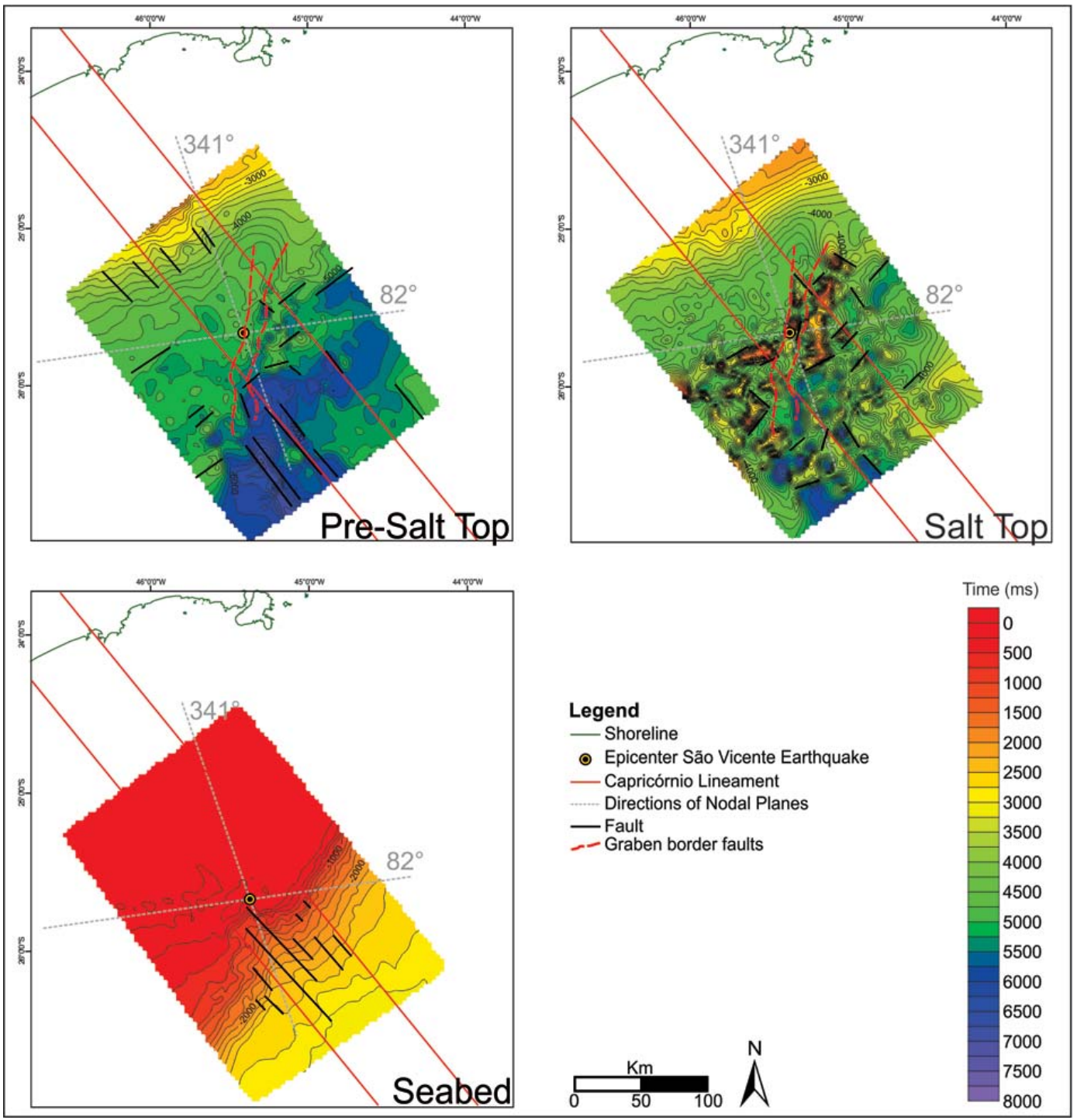

Figure 8 - Correlation of contour maps with direction of nodal planes of the São Vicente earthquake.

like to acknowledge the "Programa de Formação de Recursos Humanos em Geologia do Petróleo e Ciências Ambientais Aplicadas ao Setor de Petróleo e Gás" - PRH-05/UNESP and to PRH/Petrobras and PRH/ANP - FINEP/MCT, for academic and financial support.

\section{REFERENCES}

ASSUMPÇÃO M. 1998. Seismicity and stress in the Brazilian passive margin. Bulletin of the Seismological Society of America, 88(1): 160169.

ASSUMPÇÃO M, DOURADO JC, RIBOTTA LC, MOHRIAK WU, DIAS FL \& BARBOSA JR. 2011. The São Vicente earthquake of 2008 April and seismicity in the continental shelf off SE Brazil: further evidence for flexural stresses. Geophysical Journal International, 187: 1076-1088.

BRAZILIAN SEISMIC BULLETIN. 2013. Catálogo do Instituto Astronômico e Geofísico (IAG) da Universidade de São Paulo. Available on: $<$ http://moho.iag.usp.br/sismologia/boletim.php>. Access on: May 10, 2013.

BROWN AR. 2004. Interpretation of 3-D Seismic Data. AAPG Memoir, 6 ed., $534 \mathrm{pp}$.

BUENO GV, MACHADO Jr DL, OLIVEIRA JAB \& MARQUES EJJA. 2004. Influência do Lineamento Capricórnio na evolução tectono-sedimentar da Bacia de Santos. In: Congresso Brasileiro de Geologia, 52. 2004, Araxá. Proceedings... Araxá, Minas Gerais, Brazil: Sociedade Brasileira de Geologia. Simpósio 28., Petróleo: Geologia e Exploração, T 773. 

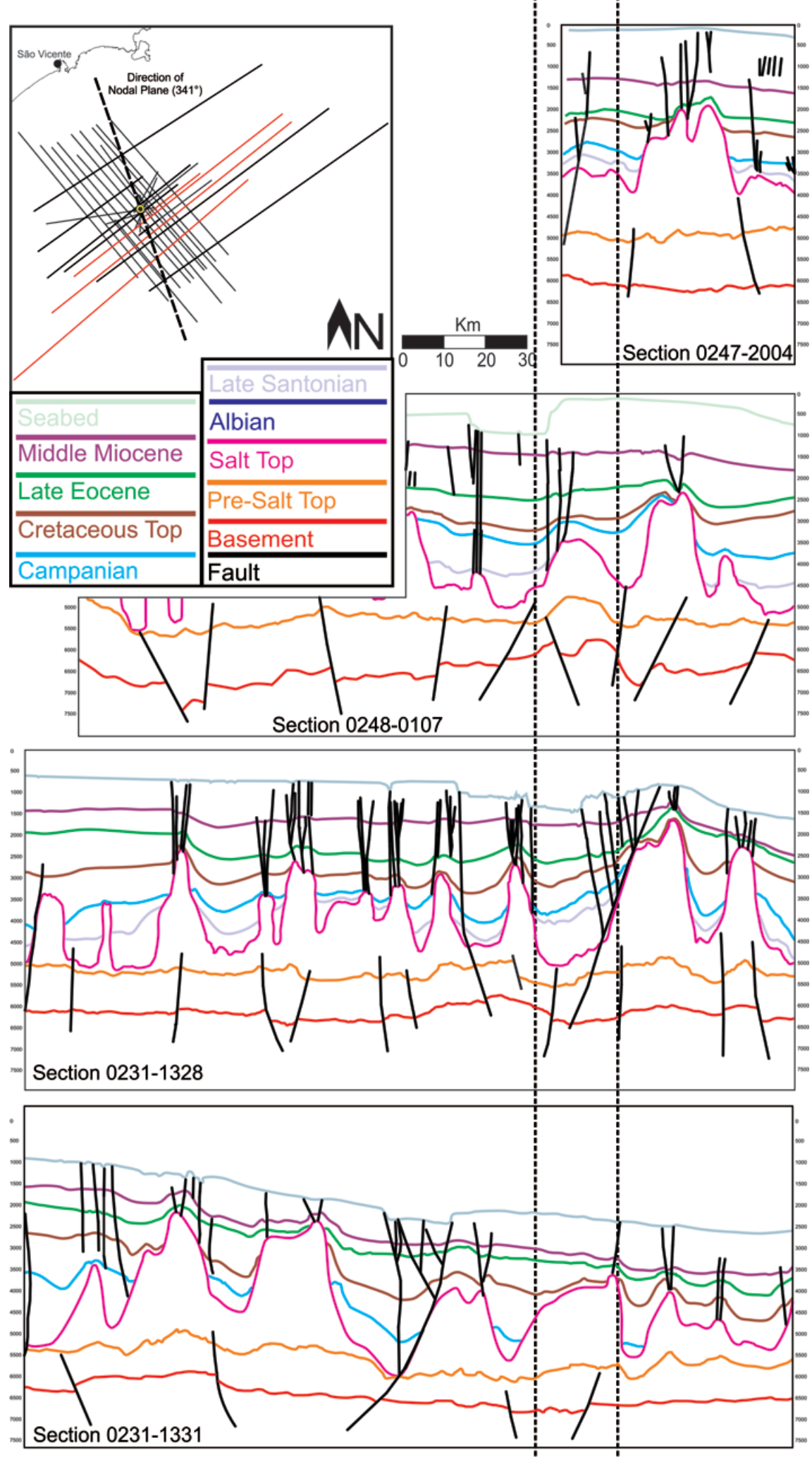

Figure 9 - Seismic interpretation correlation in the subvertical plan direction to NNW-SSE with emphasis on sections 0231-1328 and 0231-1331. 


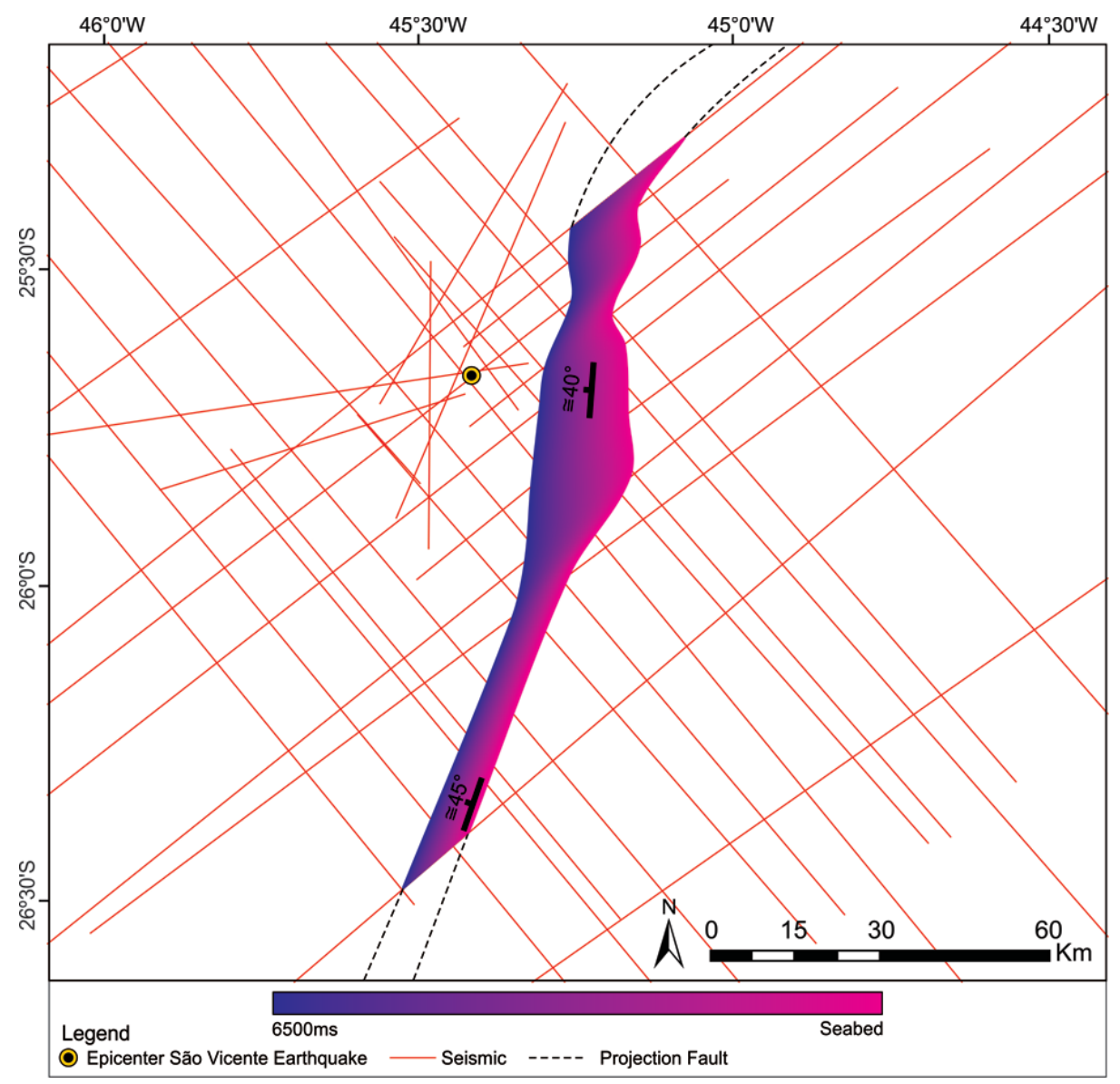

Figure 10 - Projected normal fault antithetic NS in seismic sections.

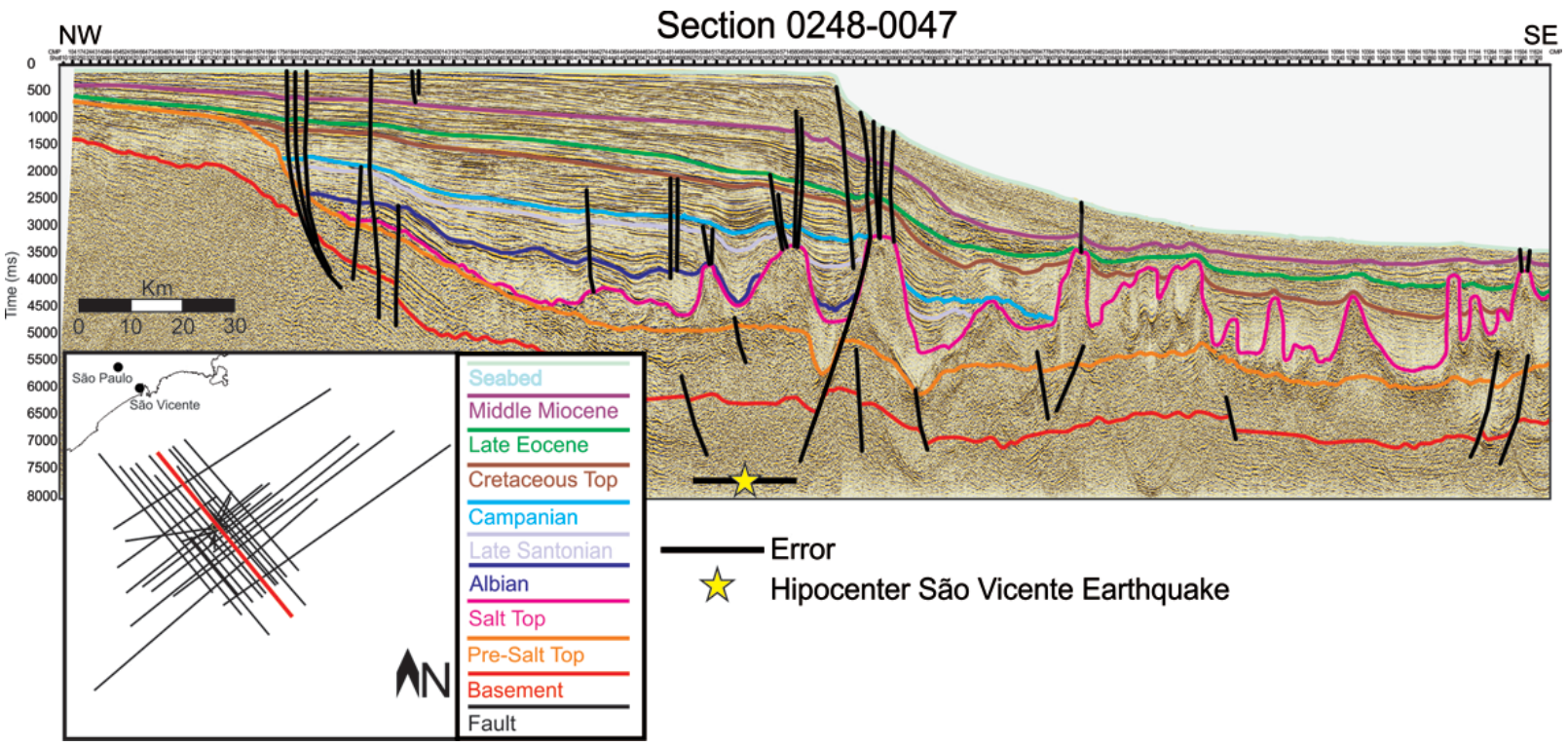

Figure 11 - Seismic section dip interpreted and hypocenter location of the earthquake. 


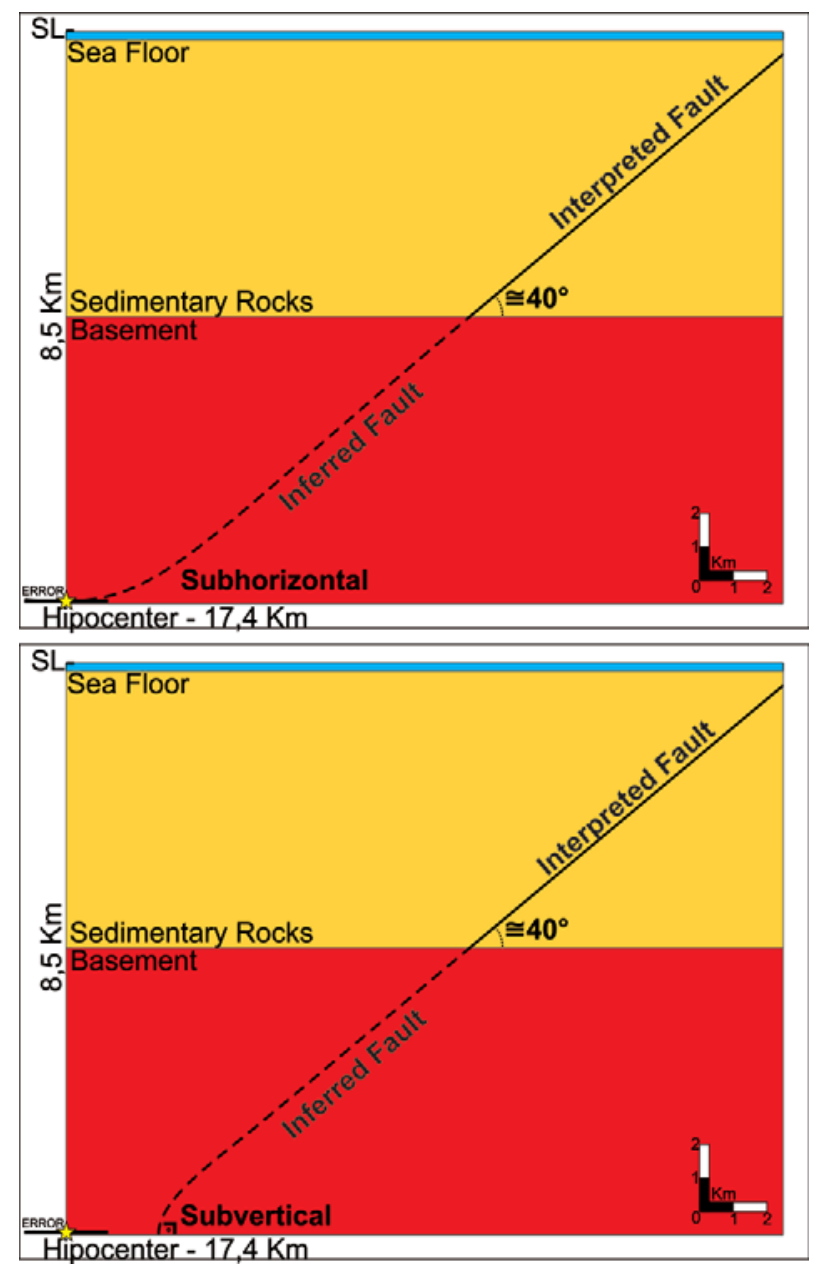

Figure 12 - Geometric projection in depth of the mapped normal antithetic fault N-S.

CALDAS MF \& ZALÁN PV. 2009. Reconstituição cinemática e tectonosedimentação associada a domos salinos nas águas profundas da Bacia de Santos, Brasil. Boletim de Geociências da Petrobras, 17(2): 227-248.

CONSTANTINO R. 2012. Utilização de dados gravimétricos derivados de altimetria por satélite e geofísica marinha no estudo de estruturas do embasamento na região da Bacia de Santos, SP. Master Dissertation, USP, São Paulo, Brazil, 70 pp.

CORRÊA FS, CHANG HK \& LETOUZEY J. 2013. Interpretação sísmica aplicada ao entendimento da evolução halocinética da região centronorte da Bacia de Santos. In: Boletim SBGf, 83: 21-23.

DEMERCIAN LS \& SZATMARI P. 1999. Thin-skinned gravitational Transfer Zone in the Southern Part of Santos Basin. In: International Congress of the Brazilian Geophysical Society, 6., Rio de Janeiro. Rio de Janeiro, Brazil: SBGf, Expanded Abstract. CD-ROM.

GARCIA SFM, DANDERFER FILHO A, LAMOTTE DF \& RUDKIEWICZ J-L. 2012. Análise de volumes de sal em restauração estrutural: um exemplo na bacia de Santos. Revista Brasileira de Geociências, 42(2): 433-450.

GEOSOFT. 2010. Filtragem Montaj MAGMAP - Tutorial e guia do usuário. Available on: <http://www.geosoft.com/pt>. Access on: December 2, 2012.

GIBBS AD. 1984. Structural evolution of extensional basin margins. Journal of the Geological Society, 141(4): 609-620.

JOHNSTON AC \& KANTER LR. 1990. Earthquakes in stable continental crust. Scientific American, 262: 68-75.

MOHRIAK WU. 2001. Salt tectonics, volcanic centers, fracture zones and their relationship with the origin and evolution of the South Atlantic Ocean: geophysical evidence in the Brazilian and West African margins. In: International Congress of Geophysical, 7., Rio de Janeiro, Brazil: SBGf, Expanded Abstract, p. 1594.

MOHRIAK WU. 2003. Bacias Sedimentares da Margem Continental Brasileira. In: BIZZI LA, SCHOBBENHAUS C, VIDOTTI RM \& 
GONÇALVES JH (Eds.). Geologia, Tectônica e Recursos Minerais do Brasil. CPRM, p. 87-168.

MOREIRA JLP, MADEIRA CV \& MACHADO MAP. 2007. Bacia de Santos. In: MILANI EJ (Coord.). Boletim de Geociências da Petrobras, 15(2): 511-529.

MOULIN M, ASLANIAN D, RABINEAU M, PATRIAT M \& MATHIAS L. 2010. Geodynamic Keys of the Santos Basin. In: II Central \& North Atlantic Conjugate Margins Conference, Lisbon, Portugal. V. VII, p. 197-201.

SCHULTE SM \& MOONEY WD. 2005. An updated global earthquake catalogue for stable continental regions: reassessing the correlation with ancient rifts. Geophysical Journal International, 161(3): 707-721.

SOUZA IA. 2008. Falhas de transferência da porção norte da Bacia de Santos interpretadas a partir de dados sísmicos: sua influência na evolução e deformação da bacia. Ph.D. Thesis. UNESP, Rio Claro, Brazil, 202 pp.

SYKES LR. 1978. Intraplate seismicity, reactivation of preexisting zones of weakness, alkaline magmatism, and other tectonism post-dating continental fragmentation. Reviews of Geophysics and Space Physics, 16: $621-688$.

TWISS RJ \& MOORESEM. 1992. Tectonics. 3 ed., 387 pp.

VAIL PR. 1987. Seismic stratigraphy interpretation using sequence stratigraphy. Part 1: seismic stratigraphy interpretation procedure. In: BALLY WA. (Ed.). Atlas of Seismic Stratigraphy, v. 1, AAPG Studies in Geology, n. 27, p. 1-10.

Recebido em 25 julho, 2013 / Aceito em 23 fevereiro, 2016

Received on July 25, 2013 / Accepted on February 23, 2016

\section{NOTES ABOUT THE AUTHORS}

Camila Schweig. Bachelor in Geophysics at Universidade Federal do Pampa - UNIPAMPA/Caçapava do Sul-RS, Brazil (2010). Master in Regional Geology at Universidade Estadual Paulista - UNESP/Rio Claro-SP, Brazil (2013). Currently, is a Geophysicist at Geoanalisys. Areas of interest: geophysical characterization of sedimentary basins.

João Carlos Dourado. Receveid B.Sc. in Geology from Universidade de São Paulo (1977) and Ph.D. degree (1997) in Geosciences from Universidade Estadual Paulista - UNESP/Rio Claro-SP, Brazil. Worked with Applied Geophysics at Instituto de Pesquisas Tecnológicas do Estado de São Paulo (IPT - Institute for Technological Research of the State of São Paulo) (1977 to 1997). Currently, is an Associated Professor of Geophysics at Universidade Estadual Paulista - UNESP/Rio Claro-SP.

lata Anderson de Souza. Bachelor in Geology at Universidade Estadual Paulista - UNESP/Rio Claro-SP, Brazil (2003). Doctor in Regional Geology at Universidade Estadual Paulista - UNESP/Rio Claro-SP, Brazil (2008). Currently, is an Assistant Academic Support IV at UNESPetro/Universidade Estadual Paulista - UNESP/Rio Claro-SP, Brazil. Areas of interest: Tectonics, GIS, Geophysics and Petroleum Geology. 